\title{
Acromegaly in a multiple endocrine neoplasia type 1 (MEN1) family with low penetrance of the disease
}

\author{
Koen M A Dreijerink, André P van Beek ${ }^{4}$, Eef G W M Lentjes ${ }^{1}$, Jan G Post ${ }^{2}$, Rob B van der Luijt ${ }^{2}$, \\ Marijke R Canninga-van Dijk ${ }^{3}$ and Cornelis J M Lips \\ Department of Endocrinology, ${ }^{1}$ Laboratory of Endocrinology, and departments of ${ }^{2}$ Medical Genetics and ${ }^{3}$ Pathology, University Medical Centre Utrecht, \\ PO Box 85.500, 3508 GA, Utrecht, The Netherlands and ${ }^{4}$ Department of Endocrinology, University Medical Centre Groningen, PO Box 30.001 , \\ 9700 RB, Groningen, The Netherlands \\ (Correspondence should be addressed to CJM Lips; Email: c.j.m.lips@azu.nl)
}

\begin{abstract}
Multiple endocrine neoplasia type 1 (MEN1) is an inherited syndrome that is characterised by the occurrence of tumours in the parathyroid glands, the endocrine pancreas, the pituitary gland and the adrenal glands and by neuroendocrine carcinoid tumours, often at a young age. The penetrance of MEN1 among gene carriers is reported to be high; $82-99 \%$ at age 50 . We present a patient with a history of parathyroid adenomas also showing signs of acromegaly. He turned out to be a carrier of a MEN1 germ-line mutation in intron 3 (IVS3-6C > G). This germ-line mutation was also found in nine of his family members. However, none of these relatives have developed any MEN1-related lesion yet, although several are older than 60 years. To our knowledge, a MEN1 family with as few clinical features as this family has not been reported to date. Because MEN1 patients have an increased risk of developing acromegaly, insulin-like growth factor (IGF-I) levels are monitored periodically. We investigated whether IGF-I levels might serve as a presymptomatic marker for acromegaly; 9\% (3/33) of MEN1 patients showed temporary IGF-I elevations. One patient (1/3) later developed clinical signs of acromegaly. Possibly, acromegaly in MEN1 is preceded by a transient preacromegalic state.
\end{abstract}

European Journal of Endocrinology 153 741-746

\section{Introduction}

Multiple endocrine neoplasia type 1 (MEN1) (see Online Mendelian Inheritance in Man (OMIM), no. 131100; URL:www.ncbi.nlm.nih.gov/entrez/query.fcgi?db=OMIM) is an autosomal dominantly inherited disorder, characterised by the occurrence of tumours of the parathyroid glands, the pituitary gland, the pancreatic islets and the adrenal cortex and neuroendocrine carcinoid tumours, often at a young age. Non-endocrine manifestations include several other tumour types, such as collagenomas, angiofibromas, lipomas and leiomyomas (1). MEN1 is caused by inactivation of germ-line mutations of the MEN1 tumour suppressor gene, which is located on chromosome 11q13 $(2,3)$. The MEN1 gene product, termed 'menin', is a 610-amino-acid protein that is expressed in all tissues, but predominantly in the nucleus (4). Menin is a regulator of gene transcription; it has been found to interact with several transcription factors, including JunD, Smad3 and NF-кB (5-7).

The identification of the MEN1 gene has enabled DNA diagnostics by mutation analysis. Identifying germ-line mutation carriers at an early age is important, since periodical clinical monitoring of mutation carriers enables presymptomatic diagnosis and treatment of lesions associated with MEN1, most likely improving both life expectancy and quality of life (8).

More than 400 different germ-line mutations have been identified, scattered throughout the entire MEN1 gene. An overview of MEN1 germ-line mutations can be found at the website of the Human Gene Mutation Database (www.hgmd.org). According to the literature, disease penetrance among MEN1 germ-line mutation carriers is $82-99 \%$ at age $50(9-11)$. Overall, a clear genotype-phenotype correlation has not been established $(12,13)$. However, in a limited number of families, MEN1 gene germ-line mutations seem to cause isolated primary hyperparathyroidism (14). Furthermore, the MEN1-Burin mutation is associated with a high prevalence of prolactinoma (15).

In this report, we present a patient with hyperparathyroidism and acromegaly. MEN1 mutation analysis showed a previously unknown MEN1 germ-line mutation. Nine family members proved to be carriers of the same mutation. Remarkably, none of these relatives showed any clinical manifestation of MEN1. Since the pathophysiological background of acromegaly is still largely unknown, and MEN1 carriers 
may develop acromegaly, we analysed 33 MEN1 patient records of our outpatient clinic for presymptomatic signs of acromegaly, particularly insulin-like growth factor I (IGF-I) levels.

\section{Index patient}

At age 38, the index patient underwent resection of two parathyroid adenomas. One year later, hypercalcaemia recurred, and he was referred to our hospital. By venous sampling, an additional parathyroid adenoma was found to be located retrosternally, embedded in thymus tissue. This tumour was removed. During physical examination, enlarged hands, coarse facial features and several collagenomas were noticed. The family history of the patient revealed that his mother died at age 62 from a medullary thyroid carcinoma with lung, bone, liver and skin metastases. His father died at age 55 from lung cancer. The postoperative workup for acromegaly revealed unsuppressible growth hormone $(\mathrm{GH})$ levels during an oral glucose tolerance test (OGTT) (19 mU/ l) (Fig. 1). From radiographic images of the skull and computed tomography scan, the presence of a tumour in the pituitary gland was suspected. A trans-sphenoidal resection was performed. Histopathological examination confirmed that a GH-producing adenoma had been removed (Fig. 2). The patient declined additional radiotherapy. Postoperatively, GH levels during an OGTT were normal $(2 \mathrm{mU} / \mathrm{l})$ (Fig. 1). None of the other pituitary functions had been affected.

After several years, periodical monitoring showed increasing IGF-I levels of 380-520 ng/ml (age- and gender-adjusted reference \pm 2 S.D.: $70-200 \mathrm{ng} / \mathrm{ml}$ ), with normal prolactin levels. Recurrence of the pituitary adenoma was suspected. However, magnetic resonance imaging (MRI) did not show recurrence of the pituitary adenoma, nor were there any abnormalities in the pancreas. Although the features of acromegaly had not increased, at age 55, the patient was

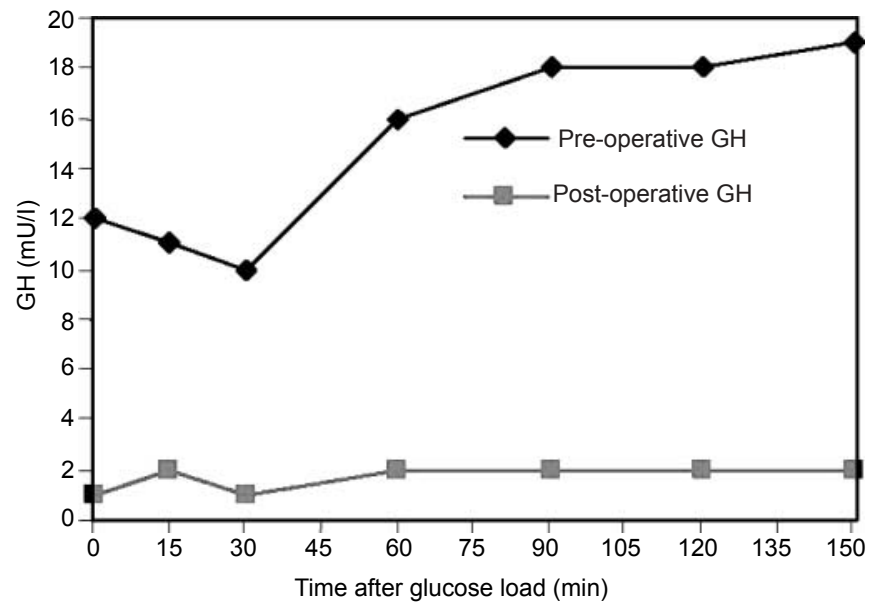

readmitted to our hospital. Diurnal GH levels and OGTT were normal (nadir $1.8 \mathrm{mU} / \mathrm{l}$ ), and colonoscopy revealed no polyps or other signs of malignancy. Combined treatment with long-acting octreotide and cabergoline reduced IGF-I levels to normal $(169 \mathrm{ng} / \mathrm{ml})$.

\section{Patients and methods}

A patient is considered a MEN1 patient when three of five major MEN1-associated lesions are present: tumours in the parathyroid glands, the pituitary gland, the pancreatic islets and the adrenal glands and neuroendocrine carcinoid tumours. A suspected MEN1 patient is defined as having two MEN1-associated lesions and/or multiple lesions within one organ and/or a MEN1-associated lesion at an early age ( $<35$ years) (16).

\section{DNA mutation analysis}

In the Netherlands, MEN1 mutation analysis is available to MEN1 patients, relatives of MEN1 patients or MEN1 gene mutation carriers, and suspected MEN1 patients. DNA analysis is performed by sequencing exons 1-10 of the MEN1 gene, as well as intron/exon boundaries with intron primers, from two independent blood samples, as described previously (3).

\section{Periodical clinical monitoring of MEN1 patients}

Periodical clinical monitoring of MEN1 patients, mutation carriers and suspected MEN1 patients consists of a biannual physical examination, and measurement of serum levels of ionised calcium, chloride, phosphate, parathyroid hormone, glucose, prolactin, IGF-I, gastrin, insulin, C-peptide, glucagon, pancreas polypeptide, platelet serotonin and chromogranin A, starting at the age of 5 . In addition, starting at the age of 15 , MRI of the upper abdomen and the mediastinum (in males; to detect thymus carcinoids, which
Figure 1 Results of an oral glucose tolerance test (OGTT) of the index patient 10 months before and 2 months after trans-sphenoidal surgery. GH levels were determined before and $15,30,60,90,120$ and 150 min after intake of $75 \mathrm{~g}$ glucose. 

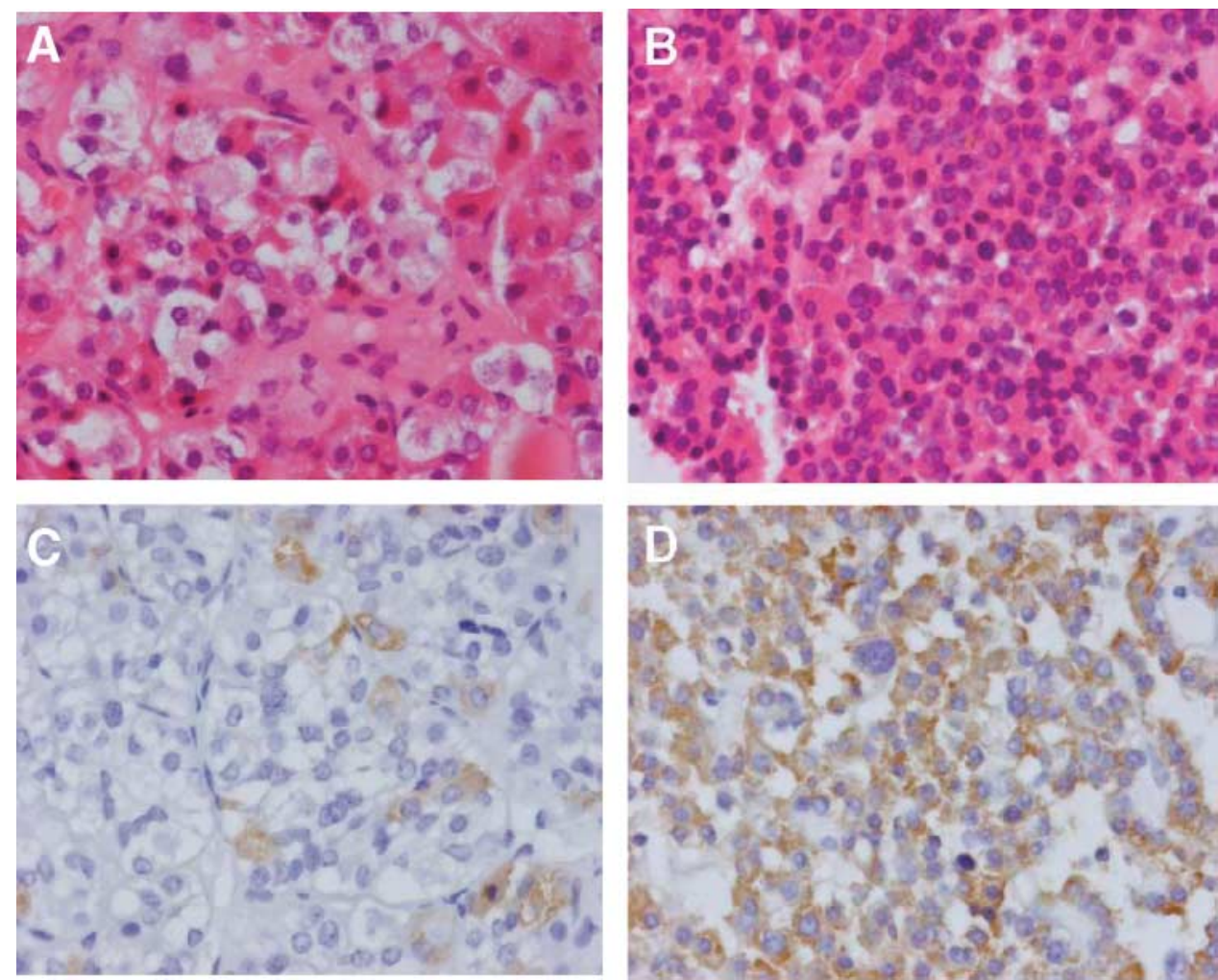

Figure 2 Histological and immunohistochemical analysis of the removed pituitary tissue. HE staining of $(A)$ normal pituitary tissue and (B) the adenomatous tissue. $\mathrm{GH}$ staining of $(\mathrm{C})$ normal pituitary tissue, containing only a few $\mathrm{GH}$-positive cells, and (D) the GH-producing adenoma. Magnification, $200 \mathrm{X}$. occur only in males), and MRI of the pituitary gland are performed every 2 years. OGTT is performed when clinical features of acromegaly are present, and/or when IGF-I levels are elevated. During OGTT, GH levels are determined before and 15, 30, 60, 90, 120 and $150 \mathrm{~min}$ after intake of $75 \mathrm{~g}$ glucose. Levels below $5 \mathrm{mU} / \mathrm{l}$ (corresponding to $2 \mathrm{ng} / \mathrm{ml}$ ) are considered normal.

\section{IGF-I measurements}

IGF-I levels were determined by chemiluminescence (Nichols Diagnostics, San Clemente, CA, USA, Advantage System). In this assay, interference of IGF-binding proteins is prevented by adding excess IGF-II to the reaction. IGF-I measurements in patient records of 33 MEN1 patients (20 females and 13 males) from 16 MEN1 families that are being monitored at the outpatient department of endocrinology over a period of 4-6 years were retrospectively analysed, and compared with gender- and age-adjusted references for IGF-I.

\section{Results}

Because the index patient had developed two tumour types associated with MEN1, and multiple parathyroid adenomas, he met the criteria for MEN1-suspected patients, and DNA analysis was performed. A C to G substitution was found in intron 3 of the MEN1 gene (intervening sequence (IVS)3-6C > G). A C to T substitution was also identified at position 7264 . The latter single-nucleotide change represents a common neutral polymorphism of the MEN1 gene, designated D418D. DNA analysis of family members led to the identification of nine MEN1 gene mutation carriers, including the patient's 64- and 66-year-old brothers and his 68-year-old sister (Fig. 3).

The (IVS)3-6C $>$ G mutation affects an acceptor splice site within exon 3 of the MEN1 gene. Calculated prediction of the change in affinity of the acceptor splice site due to this mutation indicates that the affinity of the splice site is slightly reduced compared with the wildtype, possibly leading to skipping of exon 4 or the use of an alternative cryptic splice site $(17,18)$. In peripheral leucocytes from the index patient, however, with primers directed at exons 2 and 5 of the MEN1 cDNA, no aberrantly spliced mRNA could be detected by RT-PCR.

IGF-I measurements of 33 MEN1 patients were retrospectively analysed over a period of $4-6$ years. In three patients (two female and one male; 9\%), elevations (age- and gender-adjusted reference \pm 2 S.D.) were found. In two patients, these elevations were mild. OGTT performed in these patients did not show aberrant responses. However, one patient showed gradually increasing IGF-I elevations $(344-390 \mathrm{ng} / \mathrm{ml})($ age- and gender-adjusted reference \pm 2 S.D.: $70-200 \mathrm{ng} / \mathrm{ml}$ ) even during treatment with octreotide for bronchial 
I

II
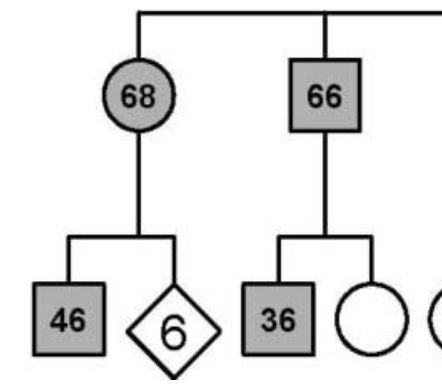
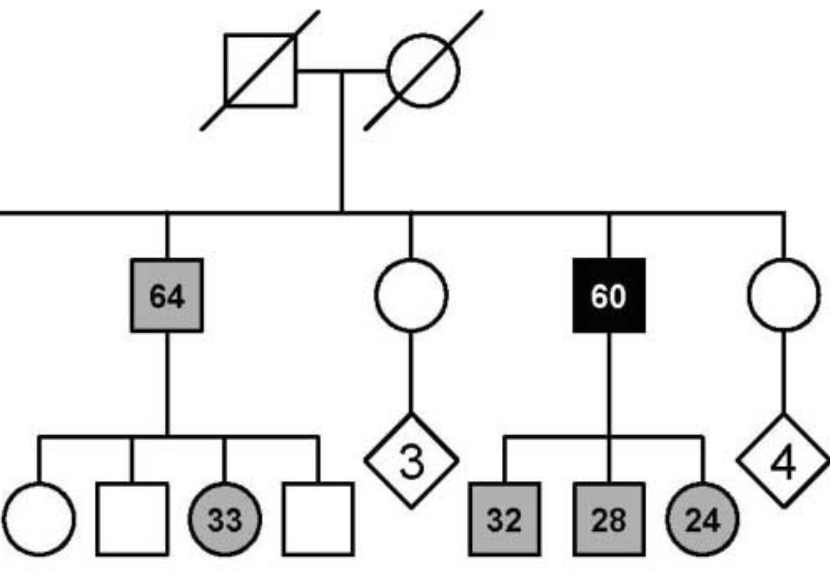

Figure 3 Pedigree of the family. Generations are indicated by Roman numerals I-III (squares represent males, circles females and diamonds males or females; black indicates clinical MEN1 (the index case, II:5), and grey indicates asymptomatic MEN1 mutation carriers). In family III:1-7, three family members were tested, and one turned out to be a carrier of the mutation. carcinoid tumours. Four years after the first IGF-I elevation, this patient had developed signs of active acromegaly, including enlarged feet, coarsened facial figures and hyperhidrosis. Since this patient had diabetes, OGTT was not performed. MRI did show slight asymmetry, but no tumour of the pituitary gland.

\section{Discussion}

\section{Low penetrance of MEN1}

In the literature, the disease penetrance of MEN1 is $82-99 \%$ at age $50(10,11)$. However, an age of onset of 86 years has been reported (10), and three of the family members of our index patient are older than 60. To our knowledge, a MEN1 family showing as few clinical features as the family described here $(10 \%)$ has not been reported to date.

An intriguing question is how to explain the low penetrance in this family. One explanation could be the nature of the mutation itself. The MEN1 germ-line mutation that was found in this family, IVS3-6C $>\mathrm{G}$, has not been reported before as a MEN1 mutation, nor as a polymorphism. In a previous study, a $\mathrm{C}$ to $\mathrm{T}$ substitution was found at the same position (IVS36C $>$ T), leading to an acceptor splice site with increased affinity upstream of exon.

This increased affinity was shown to cause skipping of exon 3, resulting in aberrant messenger RNA (mRNA) (16). This patient had both pancreatic and adrenal tumours. The same IVS3-6C $>\mathrm{T}$ germ-line mutation has also been found in a patient with a sporadic pituitary tumour (19). Two other mutations that affect the same acceptor splice site are disease-related: IVS3-1G $>$ T and IVS3-3A $>$ G $(19,20)$.

Our inability to identify aberrantly spliced MEN1 mRNA may indicate that the change of the affinity of the acceptor site might lead to only partially or tissue-specific aberrant mRNA splicing. Thus, normally spliced mRNA might still be present even if the wildtype MEN1 allele is lost. So-called leaky mutations have been reported in other inherited tumour syndromes, such as familial paraganglioma (21). Possibly, an additional predisposition that is present in the index patient, but not in his relatives, is required for this MEN1 gene mutation to be pathogenic.

Alternatively, the use of less stringent criteria for DNA analysis and the identification of more asymptomatic gene mutation carriers may eventually reveal that disease penetrance in MEN1 has been overestimated and that the true penetrance of the disease may in fact be lower, at least for certain types of mutations. This hypothesis could also explain the 'milder' MEN1 phenotypes such as familial isolated hyperparathyroidism, since a unique genotype for this phenotype has not been established (14).

\section{Aetiology and pathophysiology of acromegaly in MEN1}

Acromegaly is usually caused by a GH-secreting pituitary adenoma. The annual incidence of sporadic acromegaly is approximately 3 per million and the prevalence about 40 per million (22). GH-producing tumours causing acromegaly occur in $3-6 \%$ of MEN1 patients $(9,23)$. Two large studies showed that $13-23 \%$ of pituitary tumours in MEN1 produce GH $(19,24)$. Rarely, GH-releasing hormone (GHRH)-producing carcinoid tumours may cause pituitary hyperplasia and consecutive acromegaly $(25-28)$. Since the index patient had clearly developed a primary GH-producing pituitary adenoma, GHRH levels were not determined.

The mean age at diagnosis is about $40-45$ years in sporadic acromegaly (29), which is, in general, comparable to the age at diagnosis in MEN1 $(9,19)$. However, the earliest presentation of a $\mathrm{GH} /$ prolactin (PRL)-producing tumour in MEN1 was in a 5-year-old boy (30). The size and invasiveness of MEN1-associated, GH-producing tumours do not seem to differ significantly from sporadic tumours (31). 
Periodical clinical monitoring of MEN1 mutation carriers (who are susceptible to development of GH-producing tumours) offers an opportunity to study early signs of acromegaly. Analysis of IGF-I measurements in MEN1 patients that are monitored periodically in our hospital showed temporary elevations in $9 \%$ of MEN1 patients. Indeed, one patient with persistent IGF-I elevations later developed clinical signs of acromegaly. Interestingly, the potential existence of a 'preacromegalic' state has been suggested in two other syndromes that are characterised by $\mathrm{GH}$ excess: Carney complex (CNC) and the McCune-Albright syndrome. $\mathrm{CNC}$ is an inherited complex of spotty skin pigmentation, myxoma, increased endocrine activity and schwannoma. About $80 \%$ of $\mathrm{CNC}$ patients show paradoxical GH responses or raised IGF-I levels, whereas $10 \%$ develop active acromegaly $(32,33)$. In a recent study, $21 \%$ of McCune-Albright syndrome patients had elevated GH levels during OGTT, and in $17 \%$, IGF-I levels were elevated. In the group with IGF-I elevations, $4 / 10$ patients $(40 \%)$ had a GH-producing tumour (34).

\section{Conclusion}

We identified a MEN1 family with a IVS3(-6)C $>$ G germ-line mutation with an unusually low penetrance of the disease. Furthermore, 9\% of MEN1 patients showed elevations in IGF-I levels, which, in a single case, preceded active acromegaly. This proves the value of using IGF-I as a presymptomatic marker for detecting acromegaly in MEN1 patients.

\section{Acknowledgements}

The authors thank R Bongers and G Rabelink (Department of Medical Genetics, University Medical Centre Utrecht) for performing mutation analysis of the MEN1 gene.

\section{References}

1 Brandi ML, Gagel RF, Angeli A, Bilezikian JP, Beck-Peccoz P, Bordi C, Conte-Devolx B, Falchetti A, Gheri RG, Libroia A, Lips CJ, Lombardi G, Mannelli M, Pacini F, Ponder BA, Raue F, Skogseid B, Tamburrano G, Thakker RV, Thompson NW, Tomassetti P, Tonelli F, Wells SA Jr \& Marx SJ. Guidelines for diagnosis and therapy of MEN type 1 and type 2. Journal of Clinical Endocrinology and Metabolism 200186 5658-5671.

2 Chandrasekharappa SC, Guru SC, Manickam P, Olufemi SE, Collins FS, Emmert-Buck MR, Debelenko LV, Zhuang Z, Lubensky IA, Liotta LA, Crabtree JS, Wang Y, Roe BA, Weisemann J, Boguski MS, Agarwal SK, Kester MB, Kim YS, Heppner C, Dong Q, Spiegel AM, Burns AL \& Marx SJ. Positional cloning of the gene for multiple endocrine neoplasia-type 1 . Science $1997 \mathbf{2 7 6} 404-407$.

3 Lemmens I, Van De Ven WJ, Kas K, Zhang CX, Giraud S, Wautot V, Buisson N, De Witte K, Salandre J, Lenoir G, Pugeat M, Calender A, Parente F, Quincey D, Gaudray P, De Wit MJ, Lips CJ, Hoppener JW, Khodaei S, Grant AL, Weber G, Kytola S,
Teh BT, Farnebo F \& Thakker RV. Identification of the multiple endocrine neoplasia type 1 (MEN1) gene. The European Consortium on MEN1. Human Molecular Genetics 19976 1177-1183.

4 Guru SC, Goldsmith PK, Burns AL, Marx SJ, Spiegel a M, Collins FS \& Chandrasekharappa SC. Menin, the product of the MEN1 gene, is a nuclear protein. PNAS $1998951630-1634$.

5 Agarwal SK, Guru SC, Heppner C, Erdos MR, Collins RM, Park SY, Saggar S, Chandrasekharappa SC, Collins FS, Spiegel AM, Marx SJ \& Burns AL. Menin interacts with the AP1 transcription factor JunD and represses JunD-activated transcription. Cell $199996143-152$.

6 Kaji H, Canaff L, Lebrun JJ, Goltzman D \& Hendy GN. Inactivation of menin, a Smad3-interacting protein, blocks transforming growth factor type beta signaling. PNAS 200198 3837-3842.

7 Heppner C, Bilimoria KY, Agarwal SK, Kester M, Whitty LJ, Guru SC, Chandrasekharappa SC, Collins FS, Spiegel AM, Marx SJ \& Burns AL. The tumor suppressor protein menin interacts with NF-kappaB proteins and inhibits NF-kappaB-mediated transactivation. Oncogene 200120 4917-4925.

8 Geerdink EA, Van Der Luijt RB \& Lips CJ. Do patients with multiple endocrine neoplasia syndrome type 1 benefit from periodical screening? European Journal of Endocrinology 2003149 577-582.

9 Trump D, Farren B, Wooding C, Pang JT, Besser GM, Buchanan KD, Edwards CR, Heath DA, Jackson CE, Jansen S, Lips K, Monson JP, O'Halloran D, Sampson J, Shalet SM, Wheeler MH, Zink A \& Thakker RV. Clinical studies of multiple endocrine neoplasia type 1 (MEN1). Quarterly Journal of Medicine $199689653-669$.

10 Carty SE, Helm AK, Amico JA, Clarke MR, Foley TP, Watson CG \& Mulvihill JJ. The variable penetrance and spectrum of manifestations of multiple endocrine neoplasia type 1. Surgery 1998 124 1106-1113.

11 Bassett JH, Forbes SA, Pannett AA, Lloyd SE, Christie PT, Wooding C, Harding B, Besser GM, Edwards CR, Monson JP, Sampson J, Wass JA, Wheeler MH \& Thakker RV. Characterization of mutations in patients with multiple endocrine neoplasia type 1 . American Journal of Human Genetics 199862 232-244.

12 Wautot V, Vercherat C, Lespinasse J, Chambe B, Lenoir GM, Zhang CX, Porchet N, Cordier M, Beroud C \& Calender A. Germline mutation profile of MEN1 in multiple endocrine neoplasia type 1: search for correlation between phenotype and the functional domains of the MEN1 protein. Human Mutation 2002 $2035-47$.

13 Kouvaraki MA, Lee JE, Shapiro SE, Gagel RF, Sherman SI, Sellin RV, Cote GJ \& Evans DB. Genotype-phenotype analysis in multiple endocrine neoplasia type 1. Archives of Surgery $2002137641-647$.

14 Pannett AA, Kennedy AM, Turner JJ, Forbes SA, Cavaco BM, Bassett JH, Cianferotti L, Harding B, Shine B, Flinter F, Maidment CG, Trembath R \& Thakker RV. Multiple endocrine neoplasia type 1 (MEN1) germline mutations in familial isolated primary hyperparathyroidism. Clinical Endocrinology 200358 639-646.

15 Olufemi SE, Green JS, Manickam P, Guru SC, Agarwal SK, Kester MB, Dong Q, Burns AL, Spiegel AM, Marx SJ, Collins FS \& Chandrasekharappa SC. Common ancestral mutation in the MEN1 gene is likely responsible for the prolactinoma variant of MEN1 (MEN1Burin) in four kindreds from Newfoundland. Human Mutation 199811 264-269.

16 Roijers JF, De Wit MJ, Van Der Luijt RB, Ploos Van Amstel HK, Hoppener JW \& Lips CJ. Criteria for mutation analysis in MEN 1suspected patients: MEN 1 case-finding. European Journal of Clinical Investigation 200030 487-492.

17 Shapiro MB \& Senapathy P. RNA splice junctions of different classes of eukaryotes: sequence statistics and functional implications in gene expression. Nucleic Acids Research 198715 7155-7174.

18 Brunak S, Engelbrecht J \& Knudsen S. Prediction of human mRNA donor and acceptor sites from the DNA sequence. Journal of Molecular Biology 1991220 49-65.

19 Verges B, Boureille F, Goudet P, Murat A, Beckers A, Sassolas G, Cougard P, Chambe B, Montvernay C \& Calender A. Pituitary 
disease in MEN type 1 (MEN1): data from the France-Belgium MEN1 multicenter study. Journal of Clinical Endocrinology and Metabolism 200287 457-465.

20 Mayr B, Brabant G \& Von Zur Muhlen A. Menin mutations in MEN1 patients. Journal of Clinical Endocrinology and Metabolism 199883 3004-3005.

21 Benn DE, Croxson MS, Tucker K, Bambach CP, Richardson AL, Delbridge L, Pullan PT, Hammond J, Marsh DJ \& Robinson BG. Novel succinate dehydrogenase subunit B (SDHB) mutations in familial phaeochromocytomas and paragangliomas, but an absence of somatic SDHB mutations in sporadic phaeochromocytomas. Oncogene 200322 1358-1364.

22 Alexander L, Appleton D, Hall R, Ross WM \& Wilkinson R Epidemiology of acromegaly in the Newcastle region. Clinical Endocrinology 198012 71-79.

23 Marx S, Spiegel AM, Skarulis MC, Doppman JL, Collins FS \& Liotta LA. Multiple endocrine neoplasia type 1: clinical and genetic topics. Annals of Internal Medicine 1998129 484-494.

24 O'Brien T, O'Riordan DS, Gharib H, Scheithauer BW, Ebersold M] \& Van Heerden JA. Results of treatment of pituitary disease in multiple endocrine neoplasia, type I. Neurosurgery 1996 $39273-278$.

25 Bertherat J, Turpin G, Rauch C, Li JY, Epelbaum J, Sassolas G \& Schaison G. Presence of somatostatin receptors negatively coupled to adenylate cyclase in ectopic growth hormone-releasing hormone- and alpha-subunit-secreting tumors from acromegalic patients responsive to octreotide. Journal of Clinical Endocrinology and Metabolism 199479 1457-1464.

26 Shintani Y, Yoshimoto K, Horie H, Sano T, Kanesaki Y, Hosoi E, Yokogoshi Y, Bando H, Iwahana H \& Kannuki S. Two different pituitary adenomas in a patient with multiple endocrine neoplasia type 1 associated with growth hormone-releasing hormone-producing pancreatic tumor: clinical and genetic features. Endocrine Journal 199542 331-340.

27 Liu SW, Van De Velde CJ, Heslinga JM, Kievit J \& Roelfsema F. Acromegaly caused by growth hormone-relating hormone in a patient with multiple endocrine neoplasia type I. Japanese Journal of Clinical Oncology 199626 49-52.

28 Boix E, Pico A, Pinedo R, Aranda I \& Kovacs K. Ectopic growth hormone-releasing hormone secretion by thymic carcinoid tumour. Clinical Endocrinology 200257 131-134.

29 Melmed S. Acromegaly. New England Journal of Medicine 1990 322 966-977.

30 Stratakis CA, Schussheim DH, Freedman SM, Keil MF, Pack SD, Agarwal SK, Skarulis MC, Weil RJ, Lubensky IA, Zhuang Z, Oldfield EH \& Marx SJ. Pituitary macroadenoma in a 5-year-old: an early expression of multiple endocrine neoplasia type 1. Journal of Clinical Endocrinology and Metabolism 200085 4776-4780.

31 Beckers A, Betea D, Socin HV \& Stevenaert A. The treatment of sporadic versus MEN1-related pituitary adenomas. Journal of Internal Medicine 2003253 599-605.

32 Pack SD, Kirschner LS, Pak E, Zhuang Z, Carney JA \& Stratakis CA. Genetic and histologic studies of somatomammotropic pituitary tumors in patients with the "complex of spotty skin pigmentation, myxomas, endocrine overactivity and schwannomas' (Carney complex). Journal of Clinical Endocrinology and Metabolism 2000 $853860-3865$.

33 Stratakis CA, Kirschner LS \& Carney JA. Clinical and molecular features of the Carney complex: diagnostic criteria and recommendations for patient evaluation. Journal of Clinical Endocrinology and Metabolism 200186 4041-4046.

34 Akintoye SO, Chebli C, Booher S, Feuillan P, Kushner H, Leroith D, Cherman N, Bianco P, Wientroub S, Robey PG \& Collins MT. Characterization of gsp-mediated growth hormone excess in the context of McCune-Albright syndrome. Journal of Clinical Endocrinology and Metabolism 200287 5104-5112.

Received 8 April 2005

Accepted 1 September 2005 